Int. J. Dev. Biol. 48: 509-517 (2004)

\title{
The stroma reaction myofibroblast: a key player in the control of tumor cell behavior
}

\author{
ALEXIS DESMOULIÈRE ${ }^{*}, 1$, CHRISTELLE GUYOT $^{1}$ and GIULIO GABBIANI ${ }^{2}$ \\ ${ }^{1}$ Groupe de Recherches pour I'Etude du Foie, INSERM E0362, and Institut Fédératif de Recherche 66, Pathologies Infectieuses et Cancers, \\ Université Victor Segalen Bordeaux 2, Bordeaux, France and ${ }^{2}$ Department of Pathology, Centre Médical Universitaire, Geneva, Switzerland
}

\begin{abstract}
The cooperation between epithelial and mesenchymal cells is essential for embryonic development and probably plays an important role in pathological phenomena such as wound healing and tumor progression. It is well known that many epithelial tumors are characterized by the local accumulation of connective tissue cells and extracellular material; this phenomenon has been called the stroma reaction. One of the cellular components of the stroma reaction is the myofibroblast, a modulated fibroblast which has acquired the capacity to neoexpress $\alpha$-smooth muscle actin, the actin isoform typical of vascular smooth muscle cells, and to synthesize important amounts of collagen and other extracellular matrix components. It is now well accepted that the myofibroblast is a key cell for the connective tissue remodeling which takes place during wound healing and fibrosis development. Myofibrobasts are capable of remodeling connective tissue but also interact with epithelial cells and other connective tissue cells and may thus control such phenomena as tumor invasion and angiogenesis. In this review we discuss the mechanisms of myofibroblast evolution during fibrotic and malignant conditions and the interaction of myofibroblasts with other cells in order to control tumor progression. On this basis we suggest that the myofibroblast may represent a new important target of antitumor therapy.
\end{abstract}

KEY WORDS: myofibroblast, stroma reaction, desmoplasia, hepatocellular carcinoma

\section{Introduction: the stroma reaction}

It is now well accepted that the coordinated activity of epithelial cells with their stroma is fundamental in controlling growth and differentiation in normal and pathological situations (Donjacour and Cunha, 1991). Examples include epithelial-mesenchymal cooperation in breast, kidney, lung, and pancreas development. Signaling may be accomplished by diffusible factors, extracellular matrix and/or direct cell to cell contacts (Donjacour and Cunha, 1991). During tumor evolution, the stroma, composed of inflammatory cells, small vessels, fibroblastic and myofibroblastic cells, and extracellular matrix components, reflects disturbed interactions between the neoplastic population and its surroundings. Fibroblasts and myofibroblasts, i.e. activated fibroblasts expressing $\alpha$ smooth muscle actin, which produce collagen and extracellular matrix proteins, constitute the "desmoplastic reaction" and have been suggested to represent an important player in the development of the invasion process (De Wever and Mareel, 2003). Evidence exists that soluble factor secretion by stroma (myo)fibroblasts influences tumor progression and invasion. Desmoplasia is considered a response of host cells to inductive stimuli exerted by tumor cells (Seemayer et al., 1979; Dvorak, 1986). Studies of phenotypic features of stroma cells in normal and pathological conditions have shown their considerable diversity; this is probably depending on varying regulatory influences which are, until now, incompletely understood (Jelaska et al., 1999). Stroma cells with myofibroblastic differentiation features are the predominant cell type in different primary and metastatic epithelial tumors and play a central role in the deposition of collagen as well as in tissue remodeling phenomena that are attributed at least in part to contractile forces generated in their cytoplasm (see below). Although the role of inflammatory cells and endothelial cells in tumor immunity (Coussens and Werb, 2002) and of neoangiogenesis in tumor progression (Carmeliet and Jain, 2000) have been well described, the role of (myo)fibroblasts in cancer evolution has not been fully elucidated at present.

Abbreviations used in this paper: $\mathrm{BM}$, bone marrow; FAP, fibroblast activation protein; FP, fusion peptide; HGF, hepatocyte growth factor; MMP, matrix metalloproteinase; PDGF, platelet-derived growth factor; SCID, severe combined immunodeficient (mice); TGF, transforming growth factor.

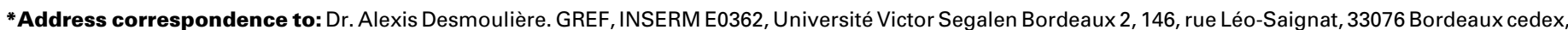
France. Fax: + 33-556-514-077. e-mail: Alexis.Desmouliere@gref.u-bordeaux2.fr
} 


\section{The myofibroblast in normal and pathological situ- ations}

\section{Normally healing wound}

During wound repair, fibroblasts participate to the formation of the granulation tissue, and modulate into myofibroblasts (for review, see Desmoulière and Gabbiani, 1996; Desmoulière et al., 2003). While normal fibroblasts contain a well developed rough endoplasmic reticulum with dilated cisternae and an oval nucleus, myofibroblasts, in addition to an abundant rough endoplasmic reticulum, neoexpress bundles of microfilaments with dense bodies similar to those found in smooth muscle cells; this feature suggests that myofibroblasts are responsible for the production of the force determining wound contraction. Fully differentiated myofibroblast express $\alpha$-smooth muscle actin; however, as underlined recently by Tomasek et al., (2002), in some situations fibroblastic cells show morphological characteristics of myofibroblasts, including microfilament bundles of cytoplasmic actins, but do not express $\alpha$-smooth muscle actin. It has been proposed to term these cells "proto-myofibroblasts" (Tomasek et al., 2002). The accumulation of proto-myofibroblasts in vivo takes place generally in the first phases of wound healing or of fibrosis formation. Usually, fibroblastic cells cultured in the presence of fetal calf serum exhibit a mixture of "proto-myofibroblastic" and more differentiated phenotypes, with varying proportions of myofibroblasts expressing $\alpha$-smooth muscle actin. It has been suggested that this heterogeneity in vitro reflects the different properties of various tissues to respond with myofibroblast differentiation to the application of fibrotic stimuli (Dugina et al., 1998). The presence of this actin isoform is directly related to the contractile activities of myofibroblasts. It has been recently demonstrated both in vitro (Hinz et al., 2001a) and in vivo (Hinz et al., $2001 \mathrm{~b}$ ), a direct correlation between the level of $\alpha$-smooth muscle actin expression and myofibroblast contraction.

Myofibroblasts and small vessels progressively disappear in the scar (Darby et al., 1990). It is conceivable that either the myofibroblastic phenotype reverts to a quiescent form when the wound is closed or myofibroblasts disappear selectively through apoptotis (Darby et al., 1990). This event has been clearly demonstrated at wound closure (Desmoulière et al., 1995).

\section{Pathological repair}

Pathological settings in which myofibroblasts represent the main cellular component may be classified into three groups: response to injury and repair phenomena (organ fibrosis), quasineoplastic proliferative conditions (fibromatosis) and stroma response to neoplasia (for review, see Schürch et al., 1992; Schmitt-Gräff et al., 1994). Furthermore, the existence of myofibroblastic tumors as bona fide neoplasms (myofibromas, myofibroblastomas, angiomyofibroblastomas, or myofibrosarcomas) seems now well admitted (Fletcher, 1998).

Inappropriate delay of apoptosis, and thus increased survival of myofibroblasts activated during the healing process, may be a factor which leads to excessive scarring such as that seen in hypertrophic scars or fibrosis. The expression of genes that are protective against apoptosis, such as $B C l-2$, has been shown to be increased in hypertrophic scars, suggesting a mechanism through which an imbalance between proliferation and apoptosis may be achieved (Teofoli et al., 1999).
The stroma reaction has been considered either a defensive mechanism to isolate the tumor, or an active process participating in the tumor progression by allowing angiogenesis and, in some instances, by facilitating the invasion and metastatisation of tumor cells. However, manisfestation and degree of the stroma reaction and of the accompanying desmoplasia are highly variable not only among different tumor categories but also within a single tumor type; the prognostic significance of the desmoplastic reaction is still controversial. In any event, desmoplasia appears to represent a type of fibrotic response to malignant cells.

\section{Myofibroblasts in the stroma}

Fibroblasts contributing to the tumor stroma have been termed peritumoral fibroblasts, reactive stroma, carcinoma-associated or tumor-associated fibroblasts (for review, see, Kunz-Schughart and Knuechel, 2002a, b). In general, fibroblastic cells adjacent to neoplastic cell nests express important amounts of $\alpha$-smooth muscle actin, as seen in the stroma of breast carcinoma (Sappino et al., 1988), metastatic malignant melanoma (Tsukamoto et al., 1992), Hodgkin's disease and myeloproliferative diseases (Toccanier-Pelte et al., 1987; Schmitt-Gräff et al., 1989); thus, fibroblastic cells of the stroma reaction are essentially well differentiated myofibroblasts. It has been shown that myofibroblasts are an extremely heterogeneous and multifunctional cell population exhibiting different phenotypes (Desmoulière and Gabbiani, 1996). Desmin and smooth muscle myosin have only been documented in a minority of such myofibroblasts (Skalli et al., 1989; Schürch et al., 1992). This pattern supports the notion that stroma myofibroblasts may correspond to modulated fibroblasts rather than to smooth muscle cells. Tumor derived cytokines are the best candidates to generate fibroblastic diversity with the emergence of myofibroblastic subsets. The positivity for $\alpha$-smooth muscle actin observed in mesenchymal cells surrounding noninvasive epithelial proliferation such as cystic duct ectasia with epithelial hyperplasia, papillomatosis, sclerosing adenosis and breast ductal carcinoma in situ (Sappino et al., 1988) as well as cervical intraepithelial neoplasia (Cintorino et al., 1991) suggests that epithelial/stroma signaling may be fundamental even before the onset of invasion. Although desmoplasia is generally considered as a response of host cells to inductive stimuli exerted by tumor cells, recent findings argue that stroma cells bare the ability to participate actively in tumor progression by secretion of proteolytic enzymes, thus allowing invasion and metastasis. Indeed, it has been known for some time that these enzymes can be secreted by neoplastic cells; in addition, it is now well admitted that an important proportion of such enzymes is produced by stroma myofibroblasts as a host response to tumor (e.g. Noel et al., 1993; Johnsen et al., 1998). Expression of stromelysin-3 gene has been demonstrated in stroma cells of invasive breast cancer (Basset et al., 1990). Poulsom et al. (1992) have shown that stroma cells of colorectal cancer have the ability to synthesize matrix metalloproteinase (MMP)-2 that degrades the basement membrane. Moreover, numerous studies correlating expression of MMP (mainly secreted by stroma myofibroblasts) with clinical parameters typically associated with prognosis of carcinomas have been reported (Nakopoulou et al., 1999; Ogata et al., 1999). Different myofibroblast subpopulations can secrete growth factors, including transforming growth factor (TGF)- $\beta$, platelet-de- 
rived growth factors (PDGF), basic fibroblast growth factor, hepatocyte growth factor (HGF), keratinocyte growth factor, stem cell factor, epithelial growth factor, granulocyte/macrophage colonystimulating factor, and other cytokines (for review, see, Powell et al., 1999a, b). Myofibroblasts in tumors also express tissue factor, the cellular initiator of the protease blood coagulation cascade leading to the formation of thrombin (Vrana et al., 1996); a strong correlation between expression of the tissue factor by macrophages and/or myofibroblasts in close proximity to infiltrating tumor cells, and progression to invasive cancer has been described. These observations suggest that stroma cells may not only be implicated in desmoplastic tissue remodeling but even contribute actively to tumor progression.

\section{Origin of the myofibroblast}

Myofibroblasts of wound tissue have been assumed to originate from local recruitment of fibroblasts in the surrounding dermis and subcutaneous tissue (Ross et al., 1970). This is supported by the presence of many fibroblasts showing proliferation marker-positive nuclei (e.g. incorporating bromodeoxyuridine) at the periphery of the wound and with MMP-positive fibroblasts suggestive of cell migration again at the wound margins (Darby et al., 1997). Another possible source of myofibroblasts is represented by pericytes or vascular smooth muscle cells around vessels in the granulation tissue.

In the last years, evidence has been provided suggesting the existence of circulating precursor cells that migrate into the wound and contribute to the fibroblastic population of granulation tissue (Abe et al., 2001). Similar evidence also exists for circulating endothelial precursor cells (Kalka et al., 2000). Indeed, Buccala et al. (1994) have identified a novel leucocyte subpopulation that has fibroblast-like properties; these cells were named fibrocytes. Peripheral blood fibrocytes can rapidly enter the site of injury at the same time as circulating inflammatory cells. Recently, it has been suggested that circulating fibrocytes may represent an important source of fibroblasts during healing of extensive burn wounds where it may be difficult for fibroblasts to migrate from the edges of the injury (Yang et al., 2002). This study has also shown that the development of fibrocytes is up-regulated systematically in burn patients; furthermore, TGF- $\beta 1$ which is elevated in the serum of burn patients (Tredget et al., 1998), stimulates the differentiation of peripheral blood mononuclear cells into collagen-producing cells, underlining again the well known role of TGF- $\beta 1$ in wound healing and scarring (Border and Ruoslahti, 1992; Desmoulière et al., 1993). Up to now, to our knowledge, the involvement of fibrocytes has not been yet described in the formation of the stroma reaction, but it is conceivable that this process could be involved when the size of the tumor increases, and when recruitment of the local fibroblasts is unable to "comply with the request".

Recently, it has been shown that bone-marrow-derived myofibroblasts contribute to the stroma reaction (Ishii et al., 2003). In this study, the human pancreatic cancer cell line Capan-1 that induces desmoplastic stroma when xenotransplanted in severe combined immunodeficient (SCID) mice was used in order to develop an animal model that would allow analysis of the pathogenesis of the cancer-induced stroma reaction. The authors used SCID mice as recipients after their bone marrow (BM) cells had been reconstituted with BM cells from $\beta$-galactosidase transgenic and recombination activating gene 1 deficient double-mutant mice. The results have shown that the stroma generated by such invasive cancer consisted of both BM-derived and non-BM-derived myofibroblasts and that BM-derived myofibroblasts were incorporated into cancer induced stroma mainly in advanced stages rather than in early stages of cancer development.

Finally, during renal fibrogenesis, it has been shown that fibroblasts arise in large numbers by local epithelial-mesenchymal transition (for review, see Kalluri and Neilson, 2003; Liu, 2004). During renal fibrosis, at the site of injury, more than a third of myofibroblasts have been shown to originate from tubular epithelial cells at the site of injury (Iwano et al., 2002). To evaluate the relevance of this process, FSP1 which is a fibroblast-specific protein in the $\mathrm{S} 100$ class of cytoplasmic calcium-binding proteins (Strutz et al., 1995), was used as marker of the fibroblastic phenotype; further work is necessary with the concomitant use of well-recognized markers of fibroblastic activation such as $\alpha$-smooth muscle actin to clearly define the process of epithelial-mesenchymal transition (or transdifferentiation), and to evaluate its role during pathological situations. In any event, it appears that epithelial/mesenchymal transition represents an alternative source of (myo)fibroblasts involved in the formation of the stroma reaction.

It should be stressed, however, that, irrespective of the origin of the lesion, the major source of fibroblasts in granulation tissue is recruitment by chemotaxis and subsequent migration from the surrounding connective tissue, as is suggested by the gradual appearance of microfilaments at the electron microscopic level and of $\alpha$-smooth muscle actin-positivity at the light microscopic level.

\section{Myofibroblasts are a major component of the stroma reaction accompanying hepatocellular carcinoma}

Injury and associated acute inflammatory response in the liver result in moderate cell necrosis and extracellular matrix damage; this is followed by tissue repair with regeneration of specialized cells, as well as formation and remodeling of granulation tissue. However, many very common liver diseases are chronic and produce fibrosis as the main complication. Chronic injury leading to fibrosis in liver occurs in response to a variety of injuries, including alcohol abuse, viral hepatitis (especially hepatitis $\mathrm{B}$ and $\mathrm{C}$ ), drugs, metabolic diseases involving overload of iron or copper, autoimmune attack of hepatocytes or bile duct epithelium, and congenital abnormalities (for review, see Friedman, 1998). Liver fibrosis is defined as the accumulation of an excess of extracellular matrix components. Its endpoint is cirrhosis that is responsible for a significant morbidity and mortality. Cirrhosis is characterized by the formation of regenerative nodules of liver parenchyma that are separated by and encapsulated in fibrotic septa (Fig. 1 A,B). These septa are populated by (myo)fibroblastic cells embedded in large amounts of extracellular matrix (Fig. 1C). In cirrhosis, CD34-expressing endothelial cells are observed essentially at the periphery of the nodules, and within the septa (Fig. 1D). It is accepted that liver 

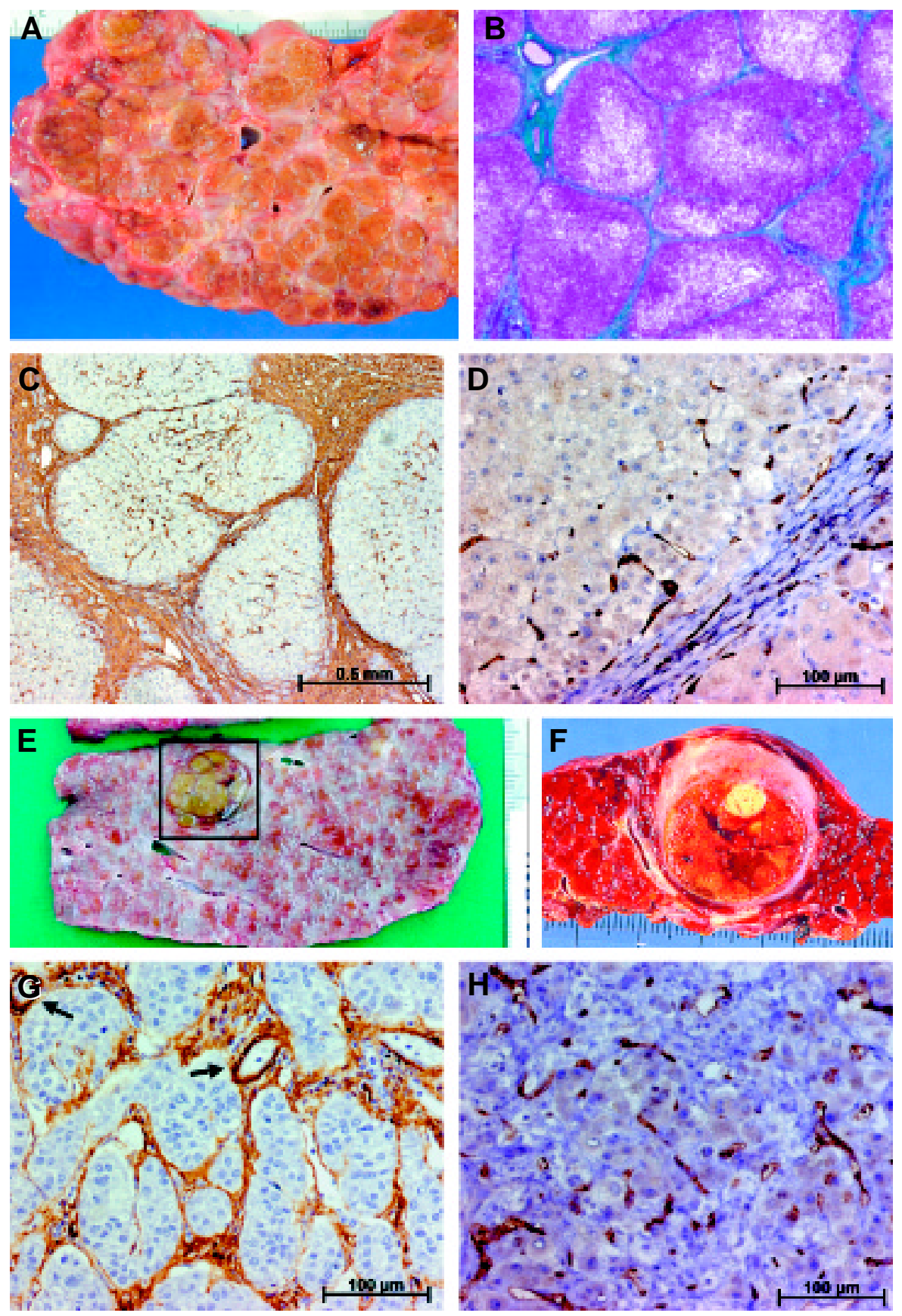

Fig.1. Cirrhosis and hepatocellular carcinoma: gross appearance; $\alpha$-smooth muscle actin and CD34 expression. (A) Gross appearance of a cirrhotic liver showing fibrous bands separating ilets of the liver parenchyma. (B) Tissue section of a cirrhotic liver stained with Masson's trichrome exhibiting fibrous septa (blue color) surrounding regenerative nodules (with steatosis). Immunohistochemistry for $\alpha$-smooth muscle actin (C) and CD34 (D) in a cirrhotic liver: in (C), numerous myofibroblasts are present in and around the cirrhotic nodules; in (D), CD34-positive endothelial cells are mainly observed at the periphery of the cirrhotic nodules and within the septa. (E) Macroscopic appearance of a hepatocellular carcinoma (frame) developed on a cirrhotic liver. (F) A more detailed image of an encapsulated small hepatocellular carcinoma developed within a cirrhotic liver. Immunohistochemistry for $\alpha$-smooth muscle actin (G) and CD34 (H) in an hepatocellular carcinoma: in (G), inside the tumor, numerous $\alpha$-smooth muscle actin expressing cells are present between tumoral hepatocytes; small arteries (arrows) are also present; in (H), CD34-positive endothelial cells underline the capillarized sinusoids inside the tumor (photos courtesy of Dr. P. Bioulac-Sage, Service d'Anatomie Pathologique, Hôpital Pellegrin, and of Dr. C. Balabaud, Service d'Hépatologie, Hôpital Saint-André, C.H.U. Bordeaux, France). fibrosis is reversible, whereas cirrhosis is generally irreversible (Bioulac-Sage et al., 2000; Iredale, 2003). Prevention of fibrosis to cirrhosis progression is thus a major clinical goal that is only partly fulfilled by the current treatments of the causative diseases. The poor prognosis of cirrhosis is in great part consecutive to the frequent occurrence of hepatocellular carcinoma, which is usually characterized by an important stroma reaction (Fig. $1 \mathrm{E}, \mathrm{F}$ ).

Extracellular matrix deposition, and stroma formation are consecutive to the activity of liver myofibroblasts. Myofibroblasts are practically absent from normal liver; they derive from the activation of precursor cells, the best studied being hepatic stellate cells (Reeves and Friedman, 2002). Hepatic stellate cells are characterized by their perisinusoidal localization, their long processes extending along and around sinusoids and between hepatocytes, and their cytoplasmic lipid droplets. We and others have put forward the concept of heterogeneity of liver fibrogenic cells, by showing that also fibroblasts present in portal tracts play a major role in liver fibrogenesis (Tuchweber et al., 1996; Kinnman et al., 2003). Cytokines such as PDGF, TGF- $\beta 1$, and connective tissue growth factor are involved in myofibroblastic differentiation. Myofibroblasts play a major role in the formation of septa observed in liver fibrosis and cirrhosis, and are also a major component of the stroma reaction which develops around hepatocellular carcinoma (Fig. 1G). In addition, myofibroblasts deriving from hepatic stellate cells can play a role in the capillarization of the sinusoids and in the neovascularization of the tumor (angiogenesis) which facilitates the formation of metastasis (Olaso et al., 2003); in contrast with cirrhotic nodules, CD34-expressing endothelial cells are observed within the totality of the tumor (Fig. $1 \mathrm{H}$ ). After implanting rat hepatocellular carcinoma cells into normal and cirrhotic rat liver, it has been shown that they grow more importantly in cirrhotic liver than in normal liver; furthermore, Kupffer cells were less numerous in cirrhotic liver, resulting in markedly impaired phagocytic activity (Tsujimoto et al., 2001). The number of Kupffer cells is also decreased in hepatocellular carcinoma and this decrease has been reported to play a role in carcinogenesis (Liu et al., 2003).

Myofibroblasts are a major source of extracellular matrix components. Tumor-associated extracellular matrix contains col- 
lagen, fibrillar glycoproteins, and proteoglycans. Interestingly, the embryonic-type extracellular matrix components tenascin$\mathrm{C}$ and fibronectin ED-A, that are neoexpressed during healing wounds and tissue repair, are also observed in the stroma reaction around hepatocellular carcinomas (Yamada et al., 1992; Matsui et al., 1997). Tenascin-C expression by fibroblasts is elevated in stressed collagen gels (Chiquet-Ehrismann et al., 1994), and fibronectin ED-A is involved in myofibroblastic differentiation (Serini et al., 1998). In a recent study (Dubuisson et al., 2001), we have seen that normal liver sinusoids are characterized by the presence of fibrillin-1, while portal spaces contain in addition elastin. In hepatocellular carcinoma, fibrillin1 was present between neoplastic hepatocytes and the stroma reaction contained both fibrillin-1 and elastin. We suggest that elastin expression could be used to discriminate portal myofibroblasts from myofibroblasts derived from hepatic stellate cells. Fibrillin has been suggested to act as a classical adhesion protein (Pfaff et al., 1996; Sakamoto et al., 1996); however, our results on human myofibroblasts rather support the possibility that recombinant human fibrillin-1 polypeptides are actually anti-adhesive, albeit with distinctive degrees of activity (Lorena et al., 2004). The recombinant human fibrillin1 polypeptide $\mathrm{rF} 6 \mathrm{H}$ containing the RGD fragment (C-terminal half of fibrillin-1) slightly decreases cell adhesion at high concentrations, but does not modify cell adhesion on collagen type I or fibronectin. In contrast, the recombinant human fibrillin-1 polypeptide rF16 (N-terminal half of fibrillin-1) dose-dependently decreases cell adhesion and inhibits cell adhesion on fibronectin, although not on collagen type I. Fibrillin-1 can be cleaved into peptides with different activities by different MMP including gelatinases MMP-2 and -9, the macrophage metalloelastase MMP-12, interstitial collagenase MMP-13, membrane-type MMP-14 (also known as MT-MMP1) (Ashworth et al., 1999; Hindson et al., 1999), and stromelysin MMP-3 (Ashworth et al., 1999). Thus, it is likely that MMP activity in physiologically and pathologically remodeling connective tissues, including during tumor progression, is able to generate fibrillin-1 fragments displaying different adhesive properties. Due to their anti-adhesive properties, fibrillin-1 fragments could facilitate cell mobilization to the site of injury. In this aspect, fibrillin-1 fragments share similarities to matricelullar proteins (tenascins, thrombospondins, and SPARC) which function as adaptators and modulators of cell-matrix interactions (MurphyUllrich, 2001; Sage, 2001).

Because of the lack of a good animal model, the pathogenesis of the stroma reaction in human hepatocellular carcinoma has remained unclear. Different models have been proposed to study hepatocellular carcinoma development. However, in most of them, stroma reaction is practically absent. Recently, using a model associating diethylnitrosamine exposure and $\mathrm{N}$ nitrosomorpholine treatment (Futakuchi et al., 1999), we observed that hepatocellular carcinoma cells were surrounded by a stroma reaction resembling that observed in humans (Taras $\mathrm{D}$, Desmoulière $\mathrm{A}$, Rosenbaum J, unpublished data).

\section{Myofibroblast - tumor cell interactions}

Myofibroblasts derived from hepatic stellate cells and/or portal fibroblasts are involved in the synthesis of stroma extra- cellular matrix components (Faouzi et al., 1999; Le Bail et al., 1999; Dubuisson et al., 2001), and of extracellular matrixdegrading proteinases, such as urokinase (Monvoisin et al., 1999; Dubuisson et al., 2000) or MMP-3 (Monvoisin et al., 2002). In vitro, activated hepatic cells are a main source of MMP-2 and collagen type I induces MMP-2 activation. It has been shown that MMP-2 activity is higher in tumors arising in cirrhotic livers than in those arising in noncirrhotic livers; moreover, tumor recurrence was associated with higher collagen type I and MMP-2 mRNA levels in hepatocellular carcinomas arising in cirrhotic livers (Theret et al., 2001). Thus, a high extracellular matrix remodeling appears to favor tumor progression in hepatocellular carcimomas. Human liver myofibroblasts act on hepatocellular carcinoma cells to increase their invasiveness and these effects are blocked by addition of an antibody to HGF and all can be reproduced by adding recombinant HGF to the tumor cells, suggesting that myofibroblast-derived HGF can be involved in the pathogenesis of hepatocellular carcinoma (Neaud et al., 1997; 2000). Hepatic stellate cells also synthesize vascular endothelial growth factor (Ankoma-Sey et al., 2000), suggesting an additional contribution to the angiogenic needs of developing hepatic tumors.

Furthermore, it has been shown that hepatic stellate cell recruitment and activation into myofibroblasts during hepatocellular carcinoma is under the control of tumoral hepatocytes (Faouzi et al., 1999). Indeed, in this study, tumor cell conditioned medium elicited major morphological changes, such as spreading and generation of cytoplasmic processes. Fao and $\mathrm{H} 5$, two rat hepatocellular carcinoma cell lines, increased hepatic stellate cell proliferation, $\alpha$-smooth muscle actin expression, and gelatinase A secretion. Interestingly, expression of $\beta$-type PDGF receptor mRNA was increased by $\mathrm{H} 5$ conditioned medium but was decreased by Fao conditioned medium, indicating that, in some cases, tumor-induced activation differs from classic fibrosis-type activation. Moreover, Shao et al. (2000) have suggested that breast carcinoma-secreted PDGF is the major initiator of tumor desmoplasia.

Tumor associated myofibroblasts contribute to leucocyte migration to the site of damage by secreting chemokines, and thus influence the local immune response; similarly, myofibroblasts can be considered "sentinel cells" able to function both as structural elements and as vital immunoregulatory cells (Smith et al., 1997) in chronic inflammation as well as in stroma reaction (Silzle et al., 2004).

In order to elucidate the role of myofibroblasts in tumor development, Lieubeau et al. (1999) have compared fibroblastic reactions and their implications in the immune response in progressive and regressive rat colorectal-tumor models. Immunohistochemical analyses revealed that $\mathrm{T}$ lymphocytes and monocytes/macrophages were found at the periphery of tumors in connection with large sheaths of myofibroblasts. In vitro experiments using fibroblast- vs. myofibroblast-containing collagen gels showed that the mechanical properties of these tumor-activated myofibroblasts prevent penetration of $\mathrm{T}$ lymphocytes and macrophages within tumor nodules. These results indicate that tumor-activated myofibroblasts may reduce physical contact between cancer cells and immune cells, an essential phenomenon for effective destruction of cancer cells. These results suggest that successful immunotherapy against 


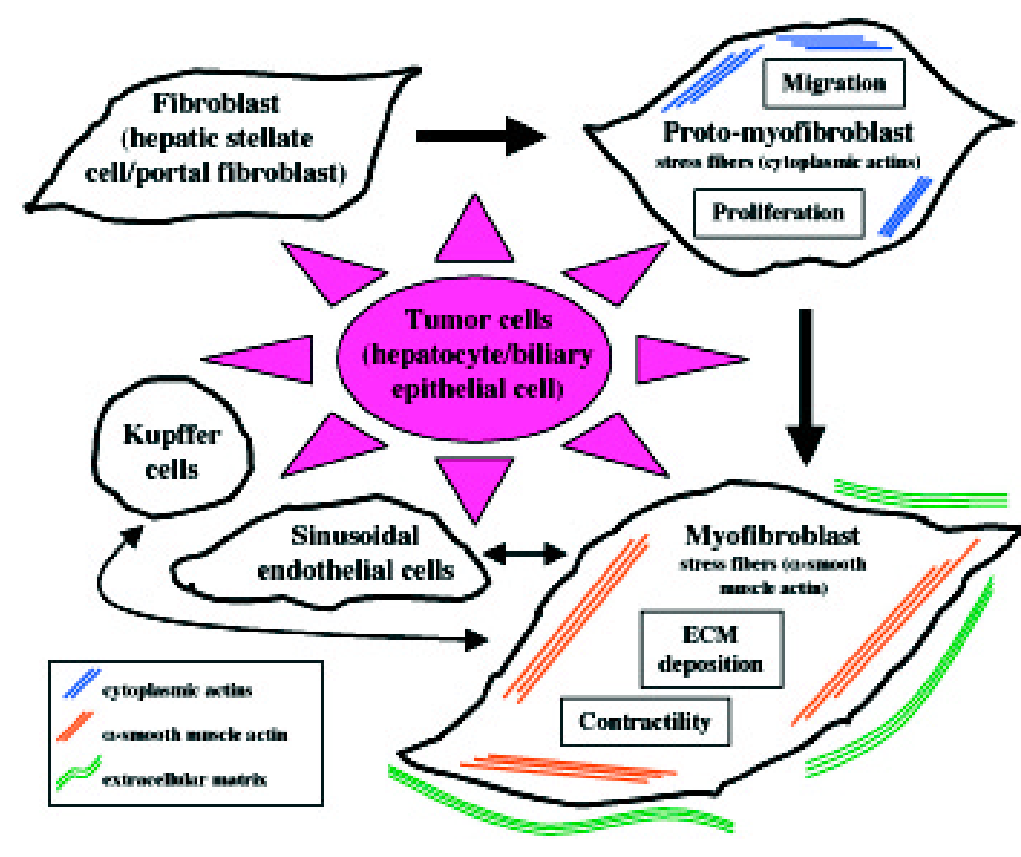

Fig. 2. Schematic illustration of the heterologous cellular interactions during hepatocellular carcinoma development and progression. Hepatocellular carcinoma are the consequence of tumoral hepatocyte proliferation; tumoral biliary epithelial cells (or cholangiocytes) produce cholangiocarcinoma. ECM, extracellular matrix.

cancer should include complementary treatments against these tumor-associated fibroblasts.

Finally, as illustrated in Fig. 2, beside interactions involving tumor cells and (myo)fibroblasts, positive or negative cooperations between tumor cells and other hepatic cells including Kupffer and endothelial cells also play an important role during tumor progression.

\section{Conclusions}

More and more evidence is presently available supporting that many important biological phenomena depend on the concerted action of epithelial and stroma cells. This is particularly evident during development or pathological phenomena, such as wound healing or cancer initiation and progression. The fibroblast/ myofibroblast transition is accepted as the key event in the formation of granulation tissue during wound healing or fibrotic changes and during the evolution of the stroma reaction. The above discussed experimental evidence points to an important role of the myofibroblast in the promotion and regulation of epithelial malignant transformation and in the maintenance of cancer progression, suggesting that the modulation of this cell, and consequently of the stroma reaction, could represent a hitherto unexplored therapeutic target for several cancer types.

Fibroblast activation protein (FAP) is a type II membrane protein expressed on tumor stroma fibroblasts in more than $90 \%$ of all carcinomas. FAP serves as a diagnostic marker and represents a potential therapeutic target for treatment of a wide variety of carcinomas. Antibodies against FAP have been developed and could be a valuable tool in the analysis of the functional role of FAP in tumour biology as well as in the evaluation of the suitability of FAP for drug targeting (Brocks et al., 2001).

Among the six slightly different but well conserved actin isoforms present in higher vertebrates, $\alpha$-smooth muscle actin appears to be responsible for conferring to several non muscle cells the capacity of exerting a high tensional activity. This is obtained through its incorporation into stress fibers, an organelle typical of cultured cells, but also present in vivoin many cell types when the necessity of producing high amount of tension arises (for review, see Hinz and Gabbiani, 2003a). Myofibroblasts are a typical example of this situation. $\alpha$ Smooth muscle actin expression is the most used marker for myofibroblast identification and allows the monitoring of the behavior of this cell during experimental and clinical situations. More recently it has been shown that $\alpha$-smooth muscle actin is also instrumental in the production of the isometric tension that characterizes the myofibroblast both in vitro and in vivo. Thus, the selective inhibition of $\alpha$-smooth muscle actin incorporation into stress fibers by the administration of its $\mathrm{N}$-terminal sequence $\mathrm{NH}_{2}$-EEED results in reduction of the tension exerted by cultured myofibroblasts on their substratum coupled with a significant decrease of collagen type I synthesis by the same cells (Hinz etal., 2002). Moreover this sequence, administered as a fusion peptide (FP) with a cell penetrating sequence, produces a significant reduction of the contractile capacity of granulation tissue strips after endothelin-1 stimulation and a significant delay of wound contraction in rat wounds splinted for 10 days and treated for the last 3 days with the FP (Hinz et al., 2002). The action of myofibroblasts in influencing tumor evolution could be exerted through at least 3 mechanisms: 1) synthesis and expression of specific extracellular matrix components; 2) mechanical remodeling of granulation tissue as well as transmission of tension to tumor cells with a mechanism involving $\alpha$-smooth muscle actin containing stress fiber isometric contraction that is mediated through Rho/ Rho-kinase; this force is then transmitted by vinculin and tensin containing focal adhesions which connect myofibroblasts to the extracellular matrix and eventually to other cells (for review, see Hinz and Gabbiani, 2003b); and 3) production of specific cytokines. The availability of a tool such as the FP capable of influencing at least the two first phenomena furnishes the opportunity for testing the extent of myofibroblast as well as of stroma reaction participation in cancer development.

In conclusion, the old and never fully proven possibility of epithelial/stroma cooperation in many biological and pathological phenomena appears at present more and more likely. The myofibroblast represents a good candidate for playing an important role in such an interaction; the recently described possibility of modulating myofibroblast behavior using new tools, such as the $\alpha$ smooth muscle actin specific FP, provides for the first time the opportunity to explore the role of this cell and of the stroma reaction in fibrotic changes and tumor evolution.

\section{References}

ABE, R., DONNELlY, S.C., PENG, T., BUCALA, R. and METZ, C.N. (2001). Peripheral blood fibrocytes: differentiation pathway and migration to wound sites. J. Immunol. 166:7556-7562. 
ANKOMA-SEY, V., WANG, Y. and DAI, Z. (2000). Hypoxic stimulation of vascular endothelial growth factor expression in activated rat hepatic stellate cells. Hepatology 31:141-148.

ASHWORTH, J.L., MURPHY, G., ROCK, M.J., SHERRATT, M.J., SHAPIRO, S.D., SHUTTLEWORTH, C.A. and KIELTY, C.M. (1999). Fibrillin degradation by matrix metalloproteinases: implications for connective tissue remodelling. Biochem. J. 340:171-181.

BASSET, P., BELLOCQ, J.P., WOLF, C., STOLL, I., HUTIN, P., LIMACHER, J.M., PODHAJCER, O.L., CHENARD, M.P., RIO, M.C. and CHAMBON, P. (1990). A novel metalloproteinase gene specifically expressed in stromal cells of breast carcinomas. Nature 348:699-704.

BIOULAC-SAGE, P., BLANC, J.F., LEPREUX, S., BALABAUD, C., ROSENBAUM, J. and DESMOULIÈRE, A. (2000). Cirrhosis: forever? Gastroenterol. Clin. Biol. 24:877-882.

BORDER, W.A. and RUOSLAHTI, E. (1992). Transforming growth factor-beta in disease: the dark side of tissue repair. J. Clin. Invest. 90:1-7.

BROCKS, B., GARIN-CHESA, P., BEHRLE, E., PARK, J.E., RETTIG, W.J., PFIZENMAIER, K. and MOOSMAYER, D. (2001). Species-crossreactive scFV against the tumor stroma marker "fibroblast activation protein" selected by phage display from an immunized FAP-/- knock-out mouse. Mol. Med. 7:461469.

BUCALA, R., SPIEGEL, L.A., CHESNEY, J., HOGAN, M. and CERAMI, A. (1994). Circulating fibrocytes define a new leukocyte subpopulation that mediates tissue repair. Mol. Med. 1:71-81.

CARMELIET, P. and JAIN, R.K. (2000). Angiogenesis in cancer and other diseases. Nature 407:249-257.

CHIQUET-EHRISMANN, R., TANNHEIMER, M., KOCH, M., BRUNNER, A., SPRING, J., MARTIN, D., BAUMGARTNER, S. and CHIQUET, M. (1994). Tenascin- $C$ expression by fibroblasts is elevated in stressed collagen gels. $J$. Cell Biol. 127:2093-2101.

CINTORINO, M., BELLIZZI DE MARCO, E., LEONCINI, P., TRIPODI, S.A., XU, L.J., SAPPINO, A.P., SCHMITT-GRÄFF, A. and GABBIANI, G. (1991). Expression of alpha-smooth-muscle actin in stromal cells of the uterine cervix during epithelial neoplastic changes. Int. J. Cancer 47:843-846.

COUSSENS, L.M. and WERB, Z. (2002). Inflammation and cancer. Nature420:860867.

DARBY, I., SKALLI, O. and GABBIANI, G. (1990). Alpha-smooth muscle actin is transiently expressed by myofibroblasts during experimental wound healing. Lab. Invest. 63:21-29.

DARBY, I.A., BISUCCI, T., HEWITSON, T.D. and MacLELLAN, D.G. (1997). Apoptosis is increased in a model of diabetes-impaired wound healing in genetically diabetic mice. Int. J. Biochem. Cell Biol. 29:191-200.

DESMOULIÈRE, A. and GABBIANI, G. (1996). The role of the myofibroblast in wound healing and fibrocontractive diseases. In The Molecular and Cellular Biology of Wound Repair (2 ${ }^{\text {nd }}$ edition). Clark RAF (ed). Plenum Publishing Corporation, New York, pp 391-423.

DESMOUlière, A., GEINOZ, A., GABBIANI, F. and GABBIANI, G. (1993). Transforming growth factor- $\beta 1$ induces $\alpha$-smooth muscle actin expression in granulation tissue myofibroblasts and in quiescent and growing cultured fibroblasts. J. Cel/ Biol. 122:103-111.

DESMOULIERE, A., REDARD, M., DARBY, I.A. and GABBIANI, G. (1995). Apoptosis mediates the decrease in cellularity during the transition between granulation tissue and scar. Am. J. Pathol. 146:55-66.

DESMOULIERE, A., DARBY, I.A. and GABBIANI, G. (2003). Normal and pathological soft tissue remodeling: role of the myofibroblast. With special emphasis on liver and kidney fibrosis. Lab. Invest. 83: 1689-1707.

DE WEVER, O, and MAREEL, M. (2003). Role of tissue stroma in cancer cell invasion. J. Pathol. 200:429-447.

DONJACOUR, A.A. and CUNHA, G.R. (1991). Stromal regulation of epithelial function. Cancer Treat. Res. 53:335-564.

DUBUISSON, L., LEPREUX, S., BIOULAC-SAGE, P., BALABAUD, C., COSTA, A.M., ROSENBAUM, J. and DESMOULIÈRE, A. (2001). Expression and cellular localization of fibrillin-1 in normal and pathological human liver. J. Hepatol. 34:514-522

DUBUISSON, L., MONVOISIN, A., NIELSEN, B.S., LE BAIL, B., BIOULAC-SAGE, P. and ROSENBAUM, J. (2000). Expression and cellular localization of the urokinase-type plasminogen activator and its receptor in human hepatocellular carcinoma. J. Pathol. 190:190-195.

DUGINA, V., ALEXANDROVA, A., CHAPONNIER, C., VASILIEV, J. and GABBIANI, G. (1998). Rat fibroblasts cultured from various organs exibit differences in alpha-smooth muscle actin expression, cytoskeletal pattern and adhesive structure organisation. Exp. Cell Res. 238:481-490.

DVORAK, H.F. (1986). Tumors: wounds that do not heal. Similarities between tumor stroma generation and wound healing. N. Engl. J. Med. 315:1650-1659.

FAOUZI, S., LE BAIL, B., NEAUD, V., BOUSSARIE, L., SARIC, J., BIOULACSAGE, P., BALABAUD, C. and ROSENBAUM, J. (1999). Myofibroblasts are responsible for collagen synthesis in the stroma of human hepatocellular carcinoma: an in vivo and in vitro study. J. Hepatol. 30:275-284.

FLETCHER, C.D. (1998). Myofibroblastic tumours: an update. Verh. Dtsch. Ges. Pathol. 82:75-82.

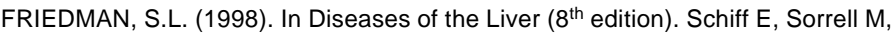
and Maddrey W (eds). Lippincott-Raven, Philadelphia, pp 371-386.

FUTAKUCHI, M., HIROSE, M., OGISO, T., KATO, K., SANO, M., OGAWA, K. and SHIRAI, T. (1999). Establishment of an in vivo highly metastatic rat hepatocellular carcinoma model. Jpn. J. Cancer Res. 90:1196-1202.

HINDSON, V.J., ASHWORTH, J.L., ROCK, M.J., CUNLIFFE, S., SHUTTLEWORTH, C.A. and KIELTY, C.M. (1999). Fibrillin degradation by matrix metalloproteinases: identification of amino- and carboxy-terminal cleavage sites. FEBS Lett. 452:195198.

HINZ, B., CELETTA, G., TOMASEK, J.J., GABBIANI, G. and CHAPONNIER, C. (2001a). Alpha-smooth muscle actin expression upregulates fibroblast contractile activity. Mol. Biol. Cel/12:2730-2741.

HINZ, B., MASTRANGELO, D., ISELIN, C.E., CHAPONNIER C. and GABBIANI, G. (2001b). Mechanical tension controls granulation tissue contractile activity and myofibroblast differentiation. Am. J. Pathol. 159:1009-1020.

HINZ, B., GABBIANI, G. and CHAPONNIER C. (2002). The NH2-terminal peptide of alpha-smooth muscle actin inhibits force generation by the myofibroblast in vitro and in vivo. J. Cell Biol. 157: 657-663.

HINZ, B. and GABBIANI, G. (2003a). Cell-matrix and cell-cell contacts of myofibroblasts: role in connective tissue remodeling. Thromb. Haemost. 90: 993-1002.

HINZ, B. and GABBIANI, G. (2003b). Mechanisms of force generation and trans mission by myofibroblasts. Curr. Opin. Biotechnol. 14:538-546.

IREDALE, J.P. (2003). Cirrhosis: new research provides a basis for rational and targeted treatments. BMJ. 327:143-147.

ISHII, G., SANGAI, T., ODA, T., AOYAGI, Y., HASEBE, T., KANOMATA, N., ENDOH, Y., OKUMURA, C., OKUHARA, Y., MAGAE, J., EMURA, M., OCHIYA, T. and OCHIAI, A. (2003). Bone-marrow-derived myofibroblasts contribute to the cancerinduced stromal reaction. Biochem. Biophys. Res. Commun. 309:232-240.

IWANO, M., PLIETH, D., DANOFF, T.M., XUE, C., OKADA, H. and NEILSON, E.G. (2002). Evidence that fibroblasts derive from epithelium during tissue fibrosis. J. Clin. Invest. 110:341-350.

JELASKA, A., STREHLOW, D. and KORN, J.H. (1999). Fibroblast heterogeneity in physiological conditions and fibrotic disease. Springer Semin. Immunopathol. 21:385-395

JOHNSEN, M., LUND, L.R., ROMER, J., ALMHOLT, K. and DANO, K. (1998) Cancer invasion and tissue remodeling: common themes in proteolytic matrix degradation. Curr. Opin. Cell Biol. 10:667-671.

KALKA, C., MASUDA, H., TAKAHASHI, T., GORDON, R., TEPPER, O., GRAVEREAUX, E., PIECZEK, A., IWAGURO, H., HAYASHI, S.I., ISNER, J.M. and ASAHARA, T. (2000). Vascular endothelial growth factor(165) gene transfer augments circulating endothelial progenitor cells in human subjects. Circ. Res. 86:1198-1202.

KALLURI, R. AND NEILSON, E.G. (2003). Epithelial-mesenchymal transition and its implications for fibrosis. J. Clin. Invest. 112:1776-1784.

KINNMAN, N., FRANCOZ, C., BARBU, V., WENDUM, D., REY, C., HULTCRANTZ, R., POUPON, R. and HOUSSET, C. (2003). The myofibroblastic conversion of peribiliary fibrogenic cells distinct from hepatic stellate cells is stimulated by platelet-derived growth factor during liver fibrogenesis. Lab. Invest. 83:163-173.

KUNZ-SCHUGHART, L.A. and KNUECHEL, R. (2002a). Tumor-associated fibroblasts (part I): Active stromal participants in tumor development and progression? Histol. Histopathol. 17:599-621. 
KUNZ-SCHUGHART, L.A. and KNUECHEL, R. (2002b). Tumor-associated fibroblasts (part II): Functional impact on tumor tissue. Histol. Histopathol. 17:623-637.

LE BAIL, B., FAOUZI, S., BOUSSARIE, L., GUIROUILH, J., BLANC, J.F., CARLES, J., BIOULAC-SAGE, P., BALABAUD, C. and ROSENBAUM, J. (1999). Osteonectin/SPARC is overexpressed in human hepatocellular carcinoma. J. Pathol. 189:46-52.

LIEUBEAU, B., HEYMANN, M.F., HENRY, F., BARBIEUX, I., MEFLAH, K. and GREGOIRE, M. (1999). Immunomodulatory effects of tumor-associated fibroblasts in colorectal-tumor development. Int. J. Cancer 81:629-636.

LIU, K., HE, X., LEI, X.Z., ZHAO, L.S., TANG, H., LIU, L. and LEI, B.J. (2003). Pathomorphological study on location and distribution of Kupffer cells in hepatocellular carcinoma. World J. Gastroenterol. 9:1946-1949.

LIU, Y. (2004). Epithelial to mesenchymal transition in renal fibrogenesis: pathologic significance, molecular mechanism, and therapeutic intervention. J. Am. Soc. Nephrol. 15:1-12

LORENA, D., DARBY, I.A., REINHARDT, D.P., SAPIN, V., ROSENBAUM, J. and DESMOULIÈRE, A. (2004). Fibrillin-1 expression in normal and fibrotic rat liver and in cultured hepatic fibroblastic cells: modulation by mechanical stress and role in cell adhesion. Lab. Invest. 84: 203-212.

MATSUI, S., TAKAHASHI, T., OYANAGI, Y., TAKAHASHI, S., BOKU, $S$. TAKAHASHI, K., FURUKAWA, K., ARAI, F. and ASAKURA, H. (1997). Expression, localization and alternative splicing pattern of fibronectin messenger RNA in fibrotic human liver and hepatocellular carcinoma. J. Hepatol. 27:843-853.

MONVOISIN, A., BISSON, C., SI-TAYEB, K., BALABAUD, C., DESMOULIÈRE, A. and ROSENBAUM, J. (2002). Involvement of matrix metalloproteinase type-3 in hepatocyte growth factor-induced invasion of human hepatocellular carcinoma cells. Int. J. Cancer97:157-162.

MONVOISIN, A., NEAUD, V., DE LÉDINGHEN, V., DUBUISSON, L., BALABAUD, C., BIOULAC-SAGE, P., DESMOULIĖRE, A. and ROSENBAUM, J. (1999). Direct evidence that hepatocyte growth factor-induced invasion of hepatocellular carcinoma cells is mediated by urokinase. J. Hepatol. 30:511-518.

MURPHY-ULLRICH, J.E. (2001). The de-adhesive activity of matricellular proteins: is intermediate cell adhesion an adaptive state? J. Clin. Invest. 107:785-790.

NAKOPOULOU, L., GIANNOPOULOU, I., GAKIOPOULOU, H., LIAPIS, H., TZONOU, A. and DAVARIS, P.S. (1999). Matrix metalloproteinase-1 and -3 in breast cancer: correlation with progesterone receptors and other clinicopathologic features. Hum. Pathol. 30:436-442.

NEAUD, V., FAOUZI, S., GUIROUILH, J., LE BAIL, B., BALABAUD, C., BIOULACSAGE, P. and ROSENBAUM, J. (1997). Human hepatic myofibroblasts increase invasiveness of hepatocellular carcinoma cells: evidence for a role of hepatocyte growth factor. Hepatology 26:1458-1466.

NEAUD, V., HISAKA, T., MONVOISIN, A., BEDIN, C., BALABAUD, C., FOSTER, D.C., DESMOULIERE, A., KISIEL, W. and ROSENBAUM, J. (2000). Paradoxical pro-invasive effect of the serine proteinase inhibitor tissue factor pathway inhibitor-2 on human hepatocellular carcinoma cells. J. Biol. Chem. 275:3556535569.

NOEL, A., MUNAUT, C., NUSGENS, B., LAPIERE, C.M. and FOIDART, J.M. (1993). Different mechanisms of extracellular matrix remodeling by fibroblasts in response to human mammary neoplastic cells. Invasion Metastasis 13:72-81.

OGATA, R., TORIMURA, T;, KIN, M., UENO, T., TATEISHI, Y., KUROMATSU, R., SHIMAUCHI, Y., SAKAMOTO, M., TAMAKI, S., SATA, M. and TANIKAWA, K. (1999). Increased expression of membrane type 1 matrix metalloproteinase and matrix metalloproteinase-2 with tumor dedifferentiation in hepatocellular carcinomas. Hum. Pathol. 30:443-450.

OLASO, E., SALADO, C., EGILEGOR, E., GUTIERREZ, V., SANTISTEBAN, A., SANCHO-BRU, P., FRIEDMAN, S.L. and VIDAL-VANACLOCHA, F. (2003). Proangiogenic role of tumor-activated hepatic stellate cells in experimental melanoma metastasis. Hepatology 37:674-685.

PETERSEN, O.W., NIELSEN, H.L., GUDJONSSON, T., VILLADSEN, R., RANK, F., NIEBUHR, E., BISSELL, M.J. and RONNOV-JESSEN, L. (2003). Epithelial to mesenchymal transition in human breast cancer can provide a nonmalignant stroma. Am. J. Pathol. 162:391-402.

PFAFF, M., REINHARDT, D.P., SAKAI, L.Y. and TIMPL, R. (1996). Cell adhesion and integrin binding to recombinant human fibrillin-1. FEBS Lett. 384:247-250.

POULSOM, R., PIGNATELLI, M., STETLER-STEVENSON, W.G., LIOTTA, L.A., WRIGHT, P.A., JEFFERY, R.E., LONGCROFT, J.M., ROGERS, L. and STAMP,
G.W. (1992). Stromal expression of 72 kda type IV collagenase (MMP-2) and TIMP-2 mRNAs in colorectal neoplasia. Am. J. Pathol. 141:389-396.

POWELL, D.W., MIFFLIN, R.C., VALENTICH, J.D., CROWE, S.E., SAADA, J.I. and WEST, A.B. (1999a). Myofibroblasts. I. Paracrine cells important in health and disease. Am. J. Physiol. 277(1 Pt 1):C1-9.

POWELL, D.W., MIFFLIN, R.C., VALENTICH, J.D., CROWE, S.E., SAADA, J.I. and WEST, A.B. (1999b). Myofibroblasts. II. Intestinal subepithelial myofibroblasts. Am. J. Physiol. 277(2 Pt 1):C183-201.

REEVES, H.L. and FRIEDMAN, S.L. (2002). Activation of hepatic stellate cells - a key issue in liver fibrosis. Front. Biosci. 7:d808-d826.

ROSS, R., EVERETT, N.B. and TYLER, R. (1970). Wound healing and collagen formation. VI. The origin of the wound fibroblast studied in parabiosis. J. Cell Biol. 44:645-654.

SAGE, E.H. (2001). Regulation of interactions between cells and extracellular matrix: a command performance on several stages. J. Clin. Invest. 107:781783.

SAKAMOTO, H., BROEKELMANN, T., CHERESH, D.A., RAMIREZ, F., ROSENBLOOM, J. and MECHAM, R.P. (1996). Cell-type specific recognition of RGD- and non-RGD-containing cell binding domains in fibrillin-1. J. Biol. Chem. 271:4916-4922.

SAPPINO, A.P., SKALLI, O., JACKSON, B., SCHÜRCH, W. and GABBIANI, G. (1988). Smooth-muscle differentiation in stromal cells of malignant and nonmalignant breast tissues. Int. J. Cancer. 41:707-712.

SCHMITT-GRÄFF, A., DESMOULIÈRE, A. and GABBIANI, G. (1994). Heterogeneity of myofibroblast phenotypic features: An example of of fibroblastic cell plasticity. Virchows Arch. 425:3-24.

SCHMITT-GRÄFF, A., SKALLI, O. and GABBIANI, G. (1989). Alpha-smooth muscle actin is expressed in a subset of bone marrow stromal cells in normal and pathological conditions. Virchows Arch. B Cell Pathol. Incl. Mol. Pathol. 57:291-302.

SCHÜRCH, W., SEEMAYER, T.A. and GABBIANI, G. (1992). Myofibroblast. In Histology for Pathologists. Sternberg SS (ed). Raven Press, New York, pp 109144.

SEEMAYER, T.A., LAGACE, R., SCHURCH, W. and TREMBLAY, G. (1979). Myofibroblasts in the stroma of invasive and metastatic carcinoma: a possible host response to neoplasia. Am. J. Surg. Pathol. 3:525-533.

SERINI, G., BOCHATON-PIALLAT, M.L., ROPRAZ, P., GEINOZ, A., BORSI, L., ZARDI, L. and GABBIANI, G. (1998). The fibronectin domain ED-A is crucial for myofibroblastic phenotype induction by transforming growth factor-beta1. J. Cell Biol. 142:873-881.

SHAO, Z.M., NGUYEN, M. and BARSKY, S.H. (2000). Human breast carcinoma desmoplasia is PDGF initiated. Oncogene 19:4337-4345.

SILZLE, T., RANDOLPH, G.J., KREUTZM. and KUNZ-SCHUGHART, L.A. (2004). The fibroblast: Sentinel cell and local immune modulator in tumor tissue. Int. $J$. Cancer 108:173-180.

SKALLI, O., SCHÜRCH, W., SEEMAYER, T., LAGACE, R., MONTANDON, D., PITTET, B. and GABBIANI, G. (1989). Myofibroblasts from diverse pathologic settings are heterogeneous in their content of actin isoforms and intermediate filament proteins. Lab. Invest. 60:275-285.

SMITH, R.S., SMITH, T.J., BLIEDEN, T.M. and PHIPPS, R.P. (1997). Fibroblasts as sentinel cells. Synthesis of chemokines and regulation of inflammation. $\mathrm{Am}$. J. Pathol. 151:317-322.

STRUTZ, F., OKADA, H., LO, C.W., DANOFF, T., CARONE, R.L., TOMASZEWSKI, J.E. and NEILSON, E.G. (1995). Identification and characterization of a fibroblast marker: FSP1. J. Cell Biol. 130:393-405.

TEOFOLI, P., BARDUAGNI, S., RIBUFFO, M., CAMPANELLA, A., DE PITA', O. and PUDDU, P. (1999). Expression of Bcl-2, p53, c-jun and c-fos protooncogenes in keloids and hypertrophic scars. J. Dermatol. Sci. 22:31-37.

THERET, N., MUSSO, O., TURLIN, B., LOTRIAN, D., BIOULAC-SAGE, P., CAMPION, J.P., BOUDJEMA, K. and CLEMENT, B. (2001). Increased extracellular matrix remodeling is associated with tumor progression in human hepatocellular carcinomas. Hepatology 34:82-88.

TOCCANIER-PELTE, M.F., SKALLI, O., KAPANCI, Y. and GABBIANI, G. (1987). Characterization of stromal cells with myoid features in lymph nodes and spleen in normal and pathologic conditions. Am. J. Pathol. 129:109-118. 
TOMASEK, J.J., GABBIANI, G., HINZ, B., CHAPONNIER, C. and BROWN, R.A. (2002). Myofibroblasts and mechano-regulation of connective tissue remodelling. Nat. Rev. Mol. Cell Biol. 3:349-363.

TREDGET, E.E., SHANKOWSKY, H.A., PANNU, R., NEDELEC, B., IWASHINA, T., GHAHARY, A., TAERUM, T.V. and SCOTT, P.G. (1998). Transforming growth factor-beta in thermally injured patients with hypertrophic scars: effects of interferon alpha-2b. Plast. Reconstr. Surg. 102:1317-1328.

TSUJIMOTO, T., KURIYAMA, S., YAMAZAKI, M., NAKATANI, Y., OKUDA, H., YOSHIJI, H. and FUKUI, H. (2001). Augmented hepatocellular carcinoma progression and depressed Kupffer cell activity in rat cirrhotic livers. Int. J. Oncol. 18:41-47.

TSUKAMOTO, H., MISHIMA, Y., HAYASHIBE, K. and SASASE, A. (1992). Alpha-smooth muscle actin expression in tumor and stromal cells of benign and malignant human pigment cell tumors. J. Invest. Dermatol. 98:116-120.
TUCHWEBER, B., DESMOULIÈRE, A., BOCHATON-PIALLAT, M.L., RUBBIABRANDT, L. and GABBIANI, G. (1996). Proliferation and phenotypic modulation of portal fibroblasts in the early stages of cholestatic fibrosis in the rat. Lab. Invest. 74:265-278.

VRANA, J.A., STANG, M.T., GRANDE, J.P. and GETZ, M.J. (1996). Expression of tissue factor in tumor stroma correlates with progression to invasive human breast cancer: paracrine regulation by carcinoma cell-derived members of the transforming growth factor beta family. Cancer Res. 56:5063-5070.

YAMADA, S., ICHIDA, T., MATSUDA, Y., MIYAZAKI, Y., HATANO, T., HATA, K., ASAKURA, H., HIROTA, N., GEERTS, A. and WISSE, E. (1992). Tenascin expression in human chronic liver disease and in hepatocellular carcinoma. Liver 12:10-16.

YANG, L., SCOTT, P.G., GIUFFRE, J., SHANKOWSKY, H.A., GHAHARY, A. and TREDGET, E.E. (2002). Peripheral blood fibrocytes from burn patients: identification and quantification of fibrocytes in adherent cells cultured from peripheral blood mononuclear cells. Lab. Invest. 82:1183-1192. 